\title{
Curriculum Implementation of Biotechnology Minor in Industrial Technology
}

\author{
Kari Clase \\ Purdue University
}

\begin{abstract}
Indiana's health industry is an extremely important and growing economic engine ${ }^{1}$. Tremendous advances are being made in pharmaceutical and biotechnology discoveries and their applications (including manufacturing), as well as in health care services. As a result, there is an increasing sophistication of the products and services available and being developed, with an ever-widening scale of applications and marketing. The growth of biotechnology results in ever-expanding needs for college graduates who have knowledge of life-science based products and processes. There have been numerous reports of current and projected shortages of human resources possessing the required knowledge in the growing industry 1 .

In order to address the gap between education and the workforce, the Department of Industrial Technology has developed an interdisciplinary academic minor in biotechnology being implemented in fall 2004. The purpose of the minor is to offer the graduates of these four-year programs the basic knowledge and understanding of lifescience based products, processes, and product quality to seek employment opportunities in the area of biotechnology and biomanufacturing.

Three courses within the biotechnology minor have been designed by faculty within the Department of Industrial Technology: Biotechnology Laboratory I, Biotechnology Laboratory II, and Bioinformatics Technology. The objectives of this paper are to describe the implementation of the new curriculum. The courses within the biotechnology minor prepare students including Industrial Technology to find careers within life science-based industries. These students will be the vanguard of a highly educated workforce contributing to the life sciences industry in Indiana.
\end{abstract}




\section{Introduction}

Indiana's health industry is an extremely important and growing economic engine ${ }^{1}$. Tremendous advances are being made in pharmaceutical and biotechnology discoveries and their applications (including manufacturing), as well as in health care services. As a result, there is an increasing sophistication of the products and services available and being developed, with an ever-widening scale of applications and marketing. This results in ever-expanding needs for college graduates who have knowledge of life-science-based products and processes. There have been numerous reports of current and projected shortages of human resources possessing the required knowledge in the growing industry ${ }^{1}$.

The need for an educated workforce in biotechnology manufacturing also exists beyond Indiana as illustrated by the following quote from Science magazine.

- "The biotechnology industry is still in its adolescence, but it is about to have a major impact on health care. A third of drugs in phase III clinical trials are proteins...biotech companies are gearing up to manufacture product but they face a shortage of talent, as most young scientists interested in biotechnology have congregated to research." 2,3,4

In order to address the gap between education and the workforce, Purdue University has approved an academic minor in Biotechnology, an interdisciplinary effort among the College of Technology, the College of Science, and the College of Pharmacy. The program is administered within the Department of Industrial Technology. The minor is available to any Purdue University student majoring in any four-year degree baccalaureate degree program, i.e., science, technology, agriculture, pharmacy. Through this partnership, laboratory activities were implemented fall 2004 to educate and train the students currently enrolled within this program. Courses that are a part of the biotechnology curriculum provide education on skills unique for life sciences manufacturing. The unique niche of this program is the focus on both biotechnology manufacturing and research.

Studies have shown that by actively engaging undergraduate students in research, their retention of scientific principles and learning retention increases. ${ }^{5,6}$ The educational objective of the biotechnology program is to create an interactive classroom learning environment and immerse undergraduate students within action-based research. Students pose authentic research questions and actively participate in the inquiry and discovery process. The students are directly involved in the experimental design, data analysis and dissemination of the results.

The courses that are a part of the biotechnology curriculum provide education on skills required for employment in biotechnology manufacturing. The students will be unique because they will have both a manufacturing knowledge base and an expertise in scientific research that will meet the rising demand by industries for competent individuals to develop and manufacture biological (life science-based) products on an industrial scale. In addition, higher order learning with action-based research and 
curriculum will increase analytical skills and better prepare students for real world jobs by enabling them to transfer curriculum-based research experiences into the biotechnology industry.

\section{Connection between Purdue University's College of Technology Strategic Plan and the Biotechnology Program}

The biotechnology program helps support the strategic plan for Purdue University by improving the learning environment for students and encouraging interdisciplinary research connections among students and faculty. In addition, the program helps harness Purdue's strengths in life sciences and technology and will provide graduates to help Indiana's future growth and development in biotechnology.

To fulfill its mission, the College of Technology strives to provide a studentcentered learning environment in which "technology-intensive instructional laboratories are maintained at state-of-the-practice currency as the keystone of practitioner-focused learning." The College of Technology strategic plan also puts importance on “...support for programs that foster the development of innovative instructional strategies, curriculum and laboratory development...” The biotechnology program is an example of a forward-thinking effort that helps fulfill the mission of the College of Technology. The biotechnology laboratory courses will enhance learning, discovery, and engagement in the following areas:

\section{Technology and Life Sciences}

- Allow students to engage in hands-on genomic, proteomic and bioinformatics life science applications within the biotechnology laboratory

\section{Security and Forensics}

- Students interested in forensics benefit from biological understanding of the processes analyzed in a forensics laboratory and they could learn the life sciences applications within the biotechnology laboratory

\section{Advanced Manufacturing}

- Industries need students that have life science skills coupled with manufacturing knowledge to prepare them for manufacturing biologically active (life-science based) products. Students that complete the biotechnology program will have the unique skills required for life science industries

Workforce Development

- Prepare graduates to achieve the integration and effective use of life science technology in the area of biotechnology through laboratory-based instruction, thus improving student learning and discovery

\section{Impact of New Course (Biotechnology Lab I)}

The biotechnology program was implemented in fall 2004 and is made up of the following courses: Fundamentals of Biology, Molecular Biology and Genetics, Cell 
Biology, Biotechnology Laboratory courses, Compliance, Process Quality Control, and Bioinformatics Technology. The first course that has been developed and offered solely for the biotechnology program is Biotechnology Lab I. Students from several departments within the College of Technology and also from the College of Science, College of Pharmacy and College of Agriculture benefit from the curriculum within this laboratory course.

The biotechnology labs emphasize experimental design with the use of appropriate instrumentation and cover several techniques employed in biotechnological research. Biotechnology Lab I is a 2 hour course intended for undergraduate students and serves as a prerequisite for Biotechnology Lab II and Introduction to Bioinformatics, courses that compose the new core curriculum in biotechnology. Biotechnology Lab I has no prerequisites and thus serves as one of the primary entry points into the biotechnology program.

\section{Courses within the biotechnology program}

\begin{tabular}{|c|c|}
\hline $\begin{array}{l}\text { Cellular } \\
\text { and } \\
\text { Molecular } \\
\text { Biology }\end{array}$ & $\begin{array}{l}\text { Biotechnology Laboratory I } \\
\text { Introduce students to biotechnology and prepare } \\
\text { students for immersion into biotechnology research } \\
\text { project }\end{array}$ \\
\hline $\begin{array}{l}\text { Good } \\
\text { Regulatory } \\
\text { Practice }\end{array}$ & $\begin{array}{l}\text { Biotechnology Laboratory II } \\
\text { Genomics and proteomics research project }\end{array}$ \\
\hline $\begin{array}{l}\text { Statistical } \\
\text { Quality }\end{array}$ & $\begin{array}{l}\text { Introduction to Bioinformatics } \\
\text { Analysis of experimental biological data derived } \\
\text { from research project }\end{array}$ \\
\hline
\end{tabular}

Due to the diverse background of the students entering Biotechnology Lab I, a questionnaire containing the following questions was prepared and distributed on the first day of class:

- What is your major?

- What are your plans after graduation? 
- Have you had any science or science lab courses in the past? If so, briefly explain the courses.

- What lab experience have you had?

- Have you had any math or computer programming courses? If so, briefly explain the courses.

- Do you have access to a computer and the internet?

- Why did you take this course?

- How would you describe biotechnology?

- Please provide an email address.

The answers helped identify the background and experience level of the students and also helped determine the expectations of the students and their preconceptions of biotechnology. One of the challenges for the class was to design curriculum that was an appropriate level for the students that would still provide a sufficient educational foundation for the subsequent biotechnology laboratory courses.

The students' answers to the questionnaire were helpful in designing the curriculum and confirmed that they had a wide range of experience. For example, one student had a significant amount of instruction in mathematics (i.e. linear algebra and advanced calculus) with no lab experience in biology. In contrast, another student had classroom lab experience in cell and molecular biology and research experience in genetics. Their definitions for biotechnology were also diverse:

- "producing technology that merges with biological structures"

- "a hands-on study of different technology aspects used in biology"

- "man-made (technology and chemistry) for a better health and life"

- "the collected group of laboratory processes used to achieve a goal more than something merely academic...the information gathered in biotechnology can be used to solve actual problems"

The unifying answer to the questionnaire was the reason stated for taking the course: an interest in the field of biotechnology and a desire to become more marketable after graduation. The questionnaires also helped determine if the students had access to the internet and were computer literate in order to ensure they were adequately prepared for the first set of course activities.

\section{Course Activities: Bioinformatics Modules}

Introductory bioinformatics modules were completed before beginning laboratory work at the bench. The bioinformatics case studies were primarily adapted from a textbook ${ }^{7}$ and helped address the students preconceived ideas of what scientific research is and what the field of biotechnology involves. In addition, the bioinformatics modules helped illustrate:

- biotechnology research does not start at a lab bench; research begins by exploring the background, discovering what other scientists have already published, and determining what research questions remain unanswered 
- inquiry and discovery within the field of biotechnology involves analysis of complex biological systems with many interacting molecules

The remainder of the Biotechnology Lab I course was composed of the following objectives and activities.

\section{Biotechnology I Course Objectives}

\begin{tabular}{|c|c|c|}
\hline General Objectives & Activities & $\begin{array}{l}\text { Learner Outcomes } \\
\text { and Assessment }\end{array}$ \\
\hline $\begin{array}{l}\text { The student will gain literacy in the basic } \\
\text { methods and applications of } \\
\text { bioinformatics }\end{array}$ & $\begin{array}{l}\text { I. Bioinformatics } \\
\text { Modules }\end{array}$ & $\begin{array}{l}\text { Bioinformatics Lab } \\
\text { Report }\end{array}$ \\
\hline $\begin{array}{l}\text { The student will be able to perform } \\
\text { techniques currently used in cell, } \\
\text { molecular, and microbiology, while } \\
\text { understanding the rationale behind the } \\
\text { specific approaches }\end{array}$ & $\begin{array}{l}\text { II. BioRad } \\
\text { Biotechnology } \\
\text { Explorer Modules }\end{array}$ & $\begin{array}{l}\text { Participation in } \\
\text { hands-on laboratory } \\
\text { activities \& Lab } \\
\text { Notebook }\end{array}$ \\
\hline $\begin{array}{l}\text { The student will be able to explain the } \\
\text { experimental basis of techniques used, } \\
\text { indicating the significance of the work, } \\
\text { presenting, calculating, and discussing } \\
\text { the data, and drawing conclusions }\end{array}$ & $\begin{array}{l}\text { II. BioRad } \\
\text { Biotechnology } \\
\text { Explorer Modules }\end{array}$ & Lab Report \\
\hline $\begin{array}{l}\text { Given a specific biological question, the } \\
\text { student will be able to determine } \\
\text { appropriate applications of specific cell, } \\
\text { molecular, and microbiological } \\
\text { techniques }\end{array}$ & $\begin{array}{l}\text { II. BioRad } \\
\text { Biotechnology } \\
\text { Explorer Modules }\end{array}$ & Lab Report \\
\hline $\begin{array}{l}\text { The student will gain experience in } \\
\text { dissecting and extracting pertinent } \\
\text { information from scientific journal } \\
\text { articles }\end{array}$ & $\begin{array}{l}\text { III. Class Discussion } \\
\text { \& Critique of } \\
\text { Scientific Journal } \\
\text { Article }\end{array}$ & $\begin{array}{l}\text { Research Report on } \\
\text { Scientific Journal } \\
\text { Article }\end{array}$ \\
\hline
\end{tabular}

\section{Course Activities: Bio Rad Biotechnology Explorer Lab Modules}

The biotechnology lab modules that were incorporated into the course were a part of the curriculum provided by the biological supply company, Bio-Rad. Bio-Rad has designed laboratory modules appropriate for an introductory biotechnology laboratory course as part of the Educational Explorer program ${ }^{8}$. The labs were selected for several reasons:

- affordable

- provide laboratory experience in a wide variety of biotechnology techniques with research quality instrumentation 
- $\quad$ provide appropriate background material to explain the techniques employed and their impact on the current field of biotechnology

- helped address biotechnology as a field with many components — both in a laboratory and within society

- $\quad$ pre-lab and post-lab focus questions that helped teach students critical thinking skills as part of the inquiry and discovery process

- minimal lab preparation time investment

- validated by several other biotechnology programs

During the first implementation of Biotechnology Lab I, the Biotechnology Explorer Lab Modules were used to provide the following biotechnology hands-on laboratory experiences:

- Deoxyribonucleic acid (DNA) and protein fingerprint analysis

- Polymerase chain reaction (PCR) informatics analysis

- DNA and protein separation by electrophoresis

- Enzyme-linked immunoabsorbant assay (ELISA) immunoassay

- Bacterial transformation and recombinant gene expression

- Protein chromatography

- Nucleic acid isolation

The laboratory activities listed above were divided into four modules:

- Bioinformatics

- DNA

- Protein

- Biotechnology Case Study

Upon completion of each module, a laboratory report was prepared in the following general format:

\begin{tabular}{|l|l|}
\hline Section & Pertinent Information \\
\hline Introduction & $\begin{array}{l}\text { Provide background information including previous work by others (cite } \\
\text { references), state the hypothesis for this current report, the significance of } \\
\text { the project, and in general, the approach used }\end{array}$ \\
\hline Methods & $\begin{array}{l}\text { State each method used, the purpose of each method and, in sentence form, } \\
\text { the method. Then add the page numbers from your lab notebook that } \\
\text { cover that protocol. }\end{array}$ \\
\hline Results & $\begin{array}{l}\text { State each result and provide data in figures and tables (with titles/legends } \\
\text {-see published papers for form). }\end{array}$ \\
\hline Discussion & $\begin{array}{l}\text { Restate results, now interpreting the findings. Compare these findings to } \\
\text { previous publications (site references). State the significance of the } \\
\text { current work and possible future directions. }\end{array}$ \\
\hline References & Cite at least 5 references using appropriate format \\
\hline
\end{tabular}


In addition, a laboratory notebook was kept to record experimental data and organize information provided for laboratory activities.

\section{Course Activities: Critique of a Scientific Journal Article}

The students were also required to provide a written critique of an assigned scientific journal article. ${ }^{9}$ A classroom discussion time was dedicated to explain the background of the paper and the research techniques employed. Students were asked to address the following questions:

- What was the hypothesis (if present) or goal?

- What is the relevant background information \& the significance of this paper and its impact on the field?

- What approach was used to address the hypothesis or accomplish the goal?

- What were the results of the paper?

o Were appropriate controls used?

o Was each figure necessary?

0 Is more data needed?

- Are their conclusions accurate (correlate well with the data presented) or are the conclusions over-stated?

- What does the work contribute to the field?

- Did the work address the hypothesis? Support or refute it?

- What is at least one future direction and the method/s to use to address it?

A rough draft was completed prior to the final deadline and returned after instructor evaluation with suggestions for improvement. It was discovered during analysis of the rough drafts that students needed additional encouragement to explore the relevant primary literature in order to provide an adequate explanation of the impact of the paper on the field and the potential future directions for research. After students addressed the comments within their rough drafts, they prepared a final paper containing a well-written, concise, summary addressing the questions stated above. 


\section{Course Evaluation}

A Small Group Instructional Diagnosis (SGID) was conducted by the Center for Instructional Excellence at Purdue University to determine what components of the curriculum were effective and what components of the curriculum were ineffective. The results from the SGID are illustrated below.

\begin{tabular}{|c|c|}
\hline \multicolumn{2}{|c|}{ Small Group Instructional Diagnosis } \\
\hline \multicolumn{2}{|c|}{ What do you like about this course? } \\
\hline Course Content & $\begin{array}{l}\text { Liked the content of the labs; allowed the students to } \\
\text { experience many areas of study }\end{array}$ \\
\hline & $\begin{array}{l}\text { Labs the students really liked: column chromatography, DNA } \\
\text { analysis lab, ELISA immunoassay }\end{array}$ \\
\hline $\begin{array}{l}\text { Instructor } \\
\text { Characteristics }\end{array}$ & $\begin{array}{l}\text { Professor Clase is really open, easy to talk to, takes } \\
\text { suggestions seriously, communicates well with students }\end{array}$ \\
\hline \multicolumn{2}{|c|}{ What specific suggestions do you have for changing this course? } \\
\hline $\begin{array}{l}\text { Course Organization } \\
\text { and Structure }\end{array}$ & Discuss some of the focus questions in class \\
\hline Course Content & $\begin{array}{l}\text { Labs the students did not like as much: Protein } \\
\text { fingerprinting, Gel electrophoresis (was nice, but hard to read } \\
\text { gels) }\end{array}$ \\
\hline Evaluation and Grading & $\begin{array}{l}\text { More of a specific goal defined for each report (i.e. what each } \\
\text { report's goal/objectives and organization were) }\end{array}$ \\
\hline
\end{tabular}

In order to address the feedback obtained from the SGID, the course will be modified:

- It is evident that the students need more specific instruction for writing laboratory reports and maintaining a laboratory notebook. For most students, this appeared to be their first exposure to this important research skill.

o Therefore, in addition to the outline format that was provided for the research laboratory notebook this semester a specific list of objectives will be prepared for each lab so the components which should be found within each section of the laboratory report are clear.

o The laboratory report will be checked as the class progresses through each section of the main lab module. This will help the students receive more structured guidance on identifying the purpose of each lab and analyzing their experimental results throughout the module.

o The goal is that the student will become more independent in maintaining a laboratory notebook by the completion of the course and grow less dependent upon the interim feedback before submitting the final lab report. 
- A different lab module will be developed to teach protein fingerprinting and protein gel electrophoresis.

- A photo documentation system will be purchased to facilitate the analysis of the gels generated from electrophoresis labs. It was very difficult to draw quantitative conclusions from the gels without measurable photographs.

The most significant change will be the addition of a lecture component to the laboratory. The lecture time will provide more time within the course to enable the following changes:

- provide background information to explain the lab and expand upon how the lab integrates into the current field of biotechnology

- facilitate more class discussion time and the addition of student presentations to strengthen student group activities

- incorporate guest seminars to allow the students to interact with professionals currently employed within various realms of the field of biotechnology

Bibliography

1. Miller, Thomas P., and Associates for Indiana Health and Industries Forum. (2002). The Indiana Health Industries Workforce Study. Retrieved October 6, 2004, from http://www.ihif.org/industryinfo.aspx

2. Kling, Jim. Careers in Biotech Manufacturing. Science’s Next Wave, April 23, 2004. Retrieved January 5, 2005 from http://nextwave.sciencemag.org/

3. Cliff Mintz, CEO of the training and staff search firm BioInsights Inc. quoted by Jim Kling. Careers in Biotech Manufacturing. Science’s Next Wave, April 23, 2004. Retrieved January 5, 2005 from http://nextwave.sciencemag.org/

4. Louet, Sabine. Get Ready to Scale Up. Science’s Next Wave, March 21, 2003. Retrieved January 5, 2005 from http://nextwave.sciencemag.org/

5. Campbell, A. Malcolm.(2004). Open Access: A PLoS for Education. PLoS Biology. 2(5): e145.

6. Wood, William B. and Gentile, James M. (2003) Teaching in a Research Context Science, 302 (5650), 1510.

7. Campbell, A. Malcolm, and Heyer, Laurie. Discovering Genomics, Proteomics, and Bioinformatics. San Francisco, California: Pearson Education, Inc. publishing as Benjamin Cummings, 2003.

8. BIO-RAD Biotechnology Explorer Program. Inquiry-based biotechnology curriculum, kits, equipment and supplies. Retrieved January 5, 2005, from http://www.explorer.bio-rad.com

9. Nobrega, Marcella, et al. (2004). Megabase deletions of gene deserts result in viable mice. Nature. 431 (7011):988-93.

Biographical Information

Kari L. Clase received her PhD in Biochemistry and Molecular Biology from Purdue University. She is the former assistant director for the Biotechnology Certificate Program at Ball State University. She is currently an assistant professor within the Department of Industrial Technology and the coordinator for the undergraduate biotechnology program at Purdue University. 